\title{
Sikap Perduli Pemerintah Terhadap Masyarakat di Kampung Menur Melalui Pendampingan KP-KAS Surabaya
}

\section{Government's Attentiveness Towards Menur Village's People Through Surabaya KP-KAS Assistance}

\author{
${ }^{1)}$ Dewi Urip Wahyuni, ${ }^{2)}$ Eka Yuliati, ${ }^{3)}$ Nur Laily, ${ }^{4 *}$ Rismawati \\ 1,2,3,4)Program Studi Manajemen, \\ Sekolah Tinggi Ilmu Ekonomi Indonesia Surabaya (STIESIA) \\ Menur Pumpungan 30 Surabaya \\ *email: dewiuripwahyuni@stiesia.ac.id, ekayuliati@stiesia.ac.id, \\ nurlaily@stiesia.ac.id, rismawati@stiesia.ac.id*
}

DOI:

10.30595/jppm.v5i1.6879

Histori Artikel:

Diajukan:

28/02/2020

Diterima:

01/04/2021

Diterbitkan:

$12 / 04 / 2021$

\section{ABSTRAK}

Pada umumnya masyarakat kurang memperhatikan proses tumbuh kembang anak sehingga anak dibiarkan untuk mencari jati diri sendiri. Orang tua kurang memperhatikan apa yang menjadi kebutuhan anaknya. Program KP-KAS sangat membantu para orang tua untuk memberikan kesadaran akan pentingnya nasib anak untuk di kemudiaan hari. Kegiatan ini bertujuan untuk mendeskripsikan tentang upaya pemerintah melalui program KP-KAS khususnya di kampung menur agar dapat tercipta kampung yang nyaman, aman, ramah dan perduli akan tumbuh kembang anak. Lokasi kegiatan di RT 01 , RT 02, RT 03 dan RW 01 Menur Surabaya. Hasil kegiatan menunjukkan adanya dukungan dari Kampung Menur untuk memberikan semangat kepada warganya terutama anak-anaknya untuk selalu memperhatikan tumbuh kembang anaknya melalui kegiatan-kegiatan yang ada di kampung dan pemasangan banner yang ada di setiap kampung yang isinya untuk selalu menghimbau para orang tua agar selalu memperhatikan nasib anaknya.

Kata kunci: Upaya Pemerintah; Sikap Perduli; KP-KAS

\section{ABSTRACT}

Generally, many people did not pay enough attention to children's development, therefore, the children were left to find their identity by themselves. Parents did not pay enough attention to their children's needs. The KPKAS program was very helpful for parents by bringing awareness on the importance of children's future. This activity aimed to describe the government's efforts through the KP-KAS program, especially in the Menur village, in order to create a village that is comfortable, safe, friendly and cares for children's development. This activity took place in RT 01, RT 02, RT 03 and RW 01 Menur Surabaya. The result of this activity showed that there was support from Menur village for its people, especially children, to always pay attention to their children development through the village's activities as well as banners installation in every village which contents were about an invitation for parents to put more attention on their children development.

Keywords: Government's Efforts; Attentiveness; KP-KAS

\section{PENDAHULUAN}

Pemerintah Kota Surabaya mulai memperhatikan nasib tumbuh kembang anak. Anak-anak adalah aset negara sehingga nantinya diharapkan dapat menjadi anak yang berguna bagi nusa dan bangsa. Tumbuh kembang anak tergantung orang tua dan lingkungan atau kampung yang juga berperan 
penting di dalam tumbuh kembang anak membentuk karakter anak (Mochklas et al. 2019. Pemerintah berupaya agar anak-anak mendapat kegiatan yang positif dan bermanfaat dan didukung oleh orang tuanya untuk sadar dan peduli terhadap anaknya. Rismaharini (2019) menyampaikan bahwa pemerintah membuat program agar anak-anak mendapat kegiatan yang positif di luar lingkungan sekolah mereka setiap hari. Kegiatan yang positif akan memberikan mereka dukungan atau support untuk keberhasilan dan kesuksesan mereka di masa depan.

Upaya pemerintah melalui Kampung Pendidikan-Kampunge Arek Suroboyo (KPKAS) diharapkan Pemerintah Kota Surabaya berupaya menumbuhkan kesadaran masyarakat kampung untuk menjadikan kampung mereka sebagai kampung Pendidikan. Salah satu program yang dilaksanakan oleh Pemerintah Kota Surabaya untuk menumbuhkan kesadaran tersebut adalah menyelenggarakan Lomba KP-KAS. Lurah Menur Nurul Muzayanah dalam Radar Surabaya (2019) warga kampungnya sangat bersyukur dengan adanya program-program yang diselenggarakan oleh Pemerintah Kota (Pemkot Surabaya) utamanya dalam membentuk kebiasaan hidup bersih dengan tidak membuang sampah sembarangan. Camat Sukolilo Amalia Kurniawati mendukung program KP-KAS ini dan berharap semoga ini langkah awal untuk RW 1 meraih yang terbaik. Kampung menur tergolong kampung pratama karena baru pertama kali mengikuti lomba KP-KAS. Kampung pratama memiliki 5 (lima) karakteristik : (1) kampung belajar, (2) kampung kreatif, (3) kampung sehat, (4) kampung asuh dan (5) kampung aman.

Tujuan dari pendampingan ini adalah membantu Kampung Menur yang termasuk dalam kelurahan Menur Pumpungan, Kecamatan Sukolilo di dalam menyusun portofolio agar mampu mengeksplorasi potensi dan keunggulan - keunggulan yang dimiliki di dalam proses tumbuh kembang anak dapat terarah sehingga nantinya akan menjadi generasi penerus bangsa yang handal. Hal ini juga tidak terlepas dari peran orang tua untuk selalu memperhatikan tumbuh kembang anaknya mengingat sekarang ini banyak hambatan yang di sebabkan oleh berkembangnya internet melalui gadget sehingga anak menjadi malas untuk belajar.

\section{METODE}

Pelaksanaan pendampingan KP-KAS di laksankan di kampung Menur RT 01, RT 02, RT 03 dan RW 01, kecamatan Sukolilo, kelurahan Menur Pumpungan yaitu dengan mengajak warga agar perduli terhadap tumbuh kembang anak dan mengajak untuk berpartisipasi melalui :

1. Kampung belajar, yaitu kampung yang mendukung kepedulian anak untuk belajar. Kampung Menur yang ada di wilayah Kecamatan Sukolilo, Kelurahan Menur Pumpungan selalu memberi dukungan kepada warganya untuk selalu memperhatikan anak - anaknya terutama dalam hal belajar, mengingat sekarang ini anak sudah ketergantungan dengan gadget dan lupa belajar maka dibutuhkan peran serta para orang tua untuk selalu memantaunya dan diikuti dengan warganya yaitu ketika anak belajar orang tua harus ikut menemaninya.

2. Kampung sehat, yaitu kampung yang dapat memberikan suasana sehat, nyaman bagi lingkungan. Kampung Menur tergolong kampung yang sangat asri, di mana setiap rumah memiliki tanaman yang cukup rindang sehingga ketika orang melihat terasa ada kesejukan. Warga kampung memasang banner agar dapat dibaca oleh semua warga sekitar yaitu dengan bertulisan bebas miras, bebas narkoba, bebas jentik/ nyamuk, bebas asap rokok.

3. Kampung kreatif, yaitu kampung yang menyediakan segala keperluan yang dibutuhkan oleh anak agar anak dapat bermain dengan temannya. Permainan yang dilakukan yaitu dengan mengenalkan kembali permainan tradisional seperti permainan dakon, permainan monopoli, permainan tali dsb. Di era milineal ini Kampung Menur juga memberikan wadah bagi mereka untuk menggambar tembok dengan gambar yang disenangi seperti : menggambar pemandangan, menggambar tokoh pahlawan dan lain - lain. 
4. Kampung asuh, yaitu kampung untuk memberi tampungan bagi anak balita yang orang tuanya bekerja. Kampung Menur mempunyai tempat untuk mengasuh anak yaitu di balai RW 01. Hal ini dilakukan untuk membantu anak - anak yang dititipkan oleh orang tuanya yang sibuk bekerja.

5. Kampung aman, yaitu kampung yang dapat menjamin keamanan bagi warga sekitar sehingga tidak ada pencurian, tamu harap lapor kalau menginap. Hal ini di lakukan agar kampung tersebut aman dari kejahatan sehingga dibutuhkan partisipasi dari semua warga agar menjadi kampung aman.

\section{HASIL DAN PEMBAHASAN}

Berdasarkan kegiatan pendampingan yang dilakukan terhadap Kampung Menur, Kelurahan Menur Pumpungan, Kecamatan Sukolilo diperoleh hasil sebagai berikut:

1. Kampung Belajar

Program ini merupakan bentuk program di mana anak-anak belajar di rumah dengan ditemani oleh orang tuanya. Kampung belajar merupakan kampong inspiratory sebagai wujud kepedulian untuk meningkatkan taraf hidup. (Hasan, 2018). Bentuk kepeduliannya di mana di suatu sudut kampung dipasang banner dan diletakkan pada tempat yang dapat dibaca oleh semua orang. Program PAUD diadakan di balai RW 01. Peran orang tua juga sangat diperlukan untuk menemani anaknya belajar agar anaknya mempunyai semangat di dalam belajar. Indikatornya adalah sebagai berikut :

a Jam belajar masyarakat (jam 18.00 19.00 WIB), yaitu diantaranya menetapkan jam yang relevan untuk waktu belajar anak (gambar 1) dan mendampingi anak belajar pada saat jam belajar (gambar 2).

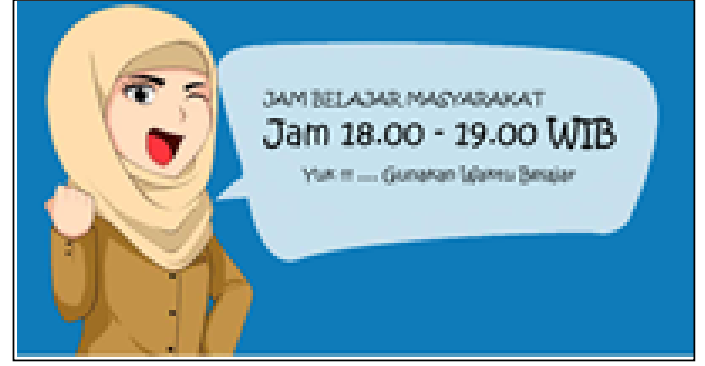

Gambar 1. Banner jam belajar

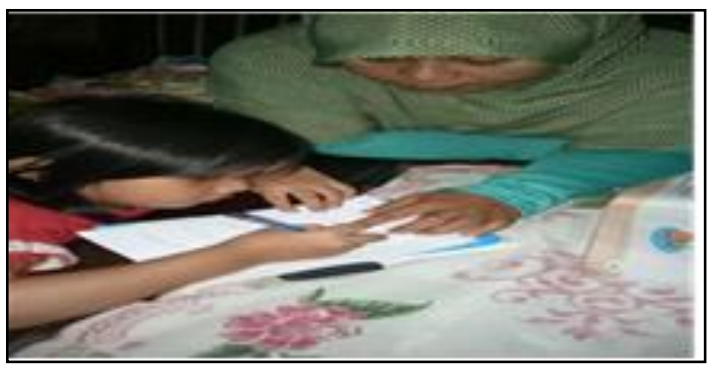

Gambar 2. Pendampingan anak pada jam belajar

b Jam pembatasan menonton TV bagi anak (maksimal pukul 18.00 WIB):

Menetapkan jam bagi anak untuk beristirahat dengan tetap mempertimbangan tayangan TV yang mendidik.

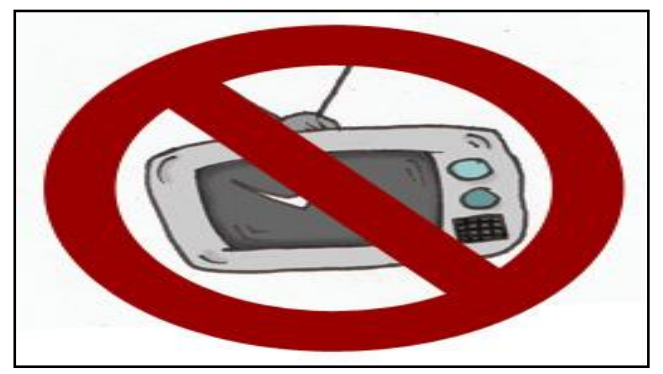

Gambar 3. Televisi

c Mendampingi anak pada saat menggunakan komputer untuk mengerjakan soal. 


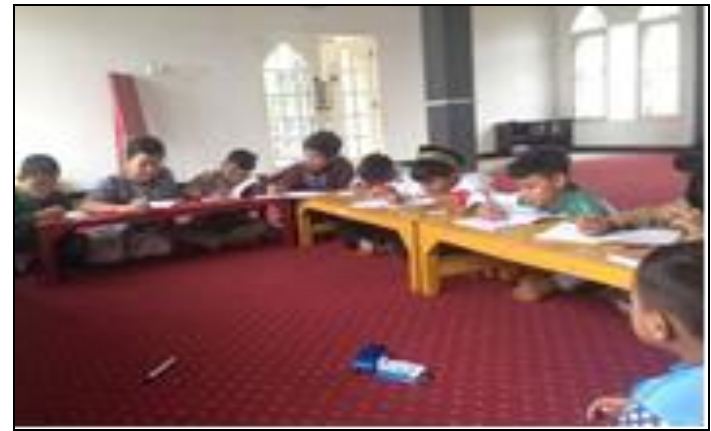

Gambar 4. Pendampingan anak belajar

\section{Kampung sehat}

Kampung sehat merupakan penerapan hidup sehat yang berbasis Perilaku Hidup Bersih dan Sehat (PHBS) dengan cara memberdayakan anggota keluarga, sehingga mampu mempraktekkan PHBS serta berperan aktif dalam gerakan kesehatan di masyarakat melalui bebas asap rokok, bebas miras, lingkungan hijau dan imunisasi. Dengan adanya kampung sehat diharapkan kepada warga memiliki komitmen untuk menciptakan suatu lingkungan bebas polusi dan asri dengan banyak pepohonan, bunga serta senantiasa memperhatikan gizi anak dan kesehatan melalui bumatik dan budaya gemar cuci tangan. Hal ini didukung oleh Pusat Promkes Depkes RI, 2011 tentang perilaku hidup bersih dan sehat merupakan perilaku yang didasarkan pada tingkat kesadaran anggota keluarga untuk menolong dirinya sendiri serta memiliki peranan yang aktif dalam kegiatan kesehatan masyarakat.

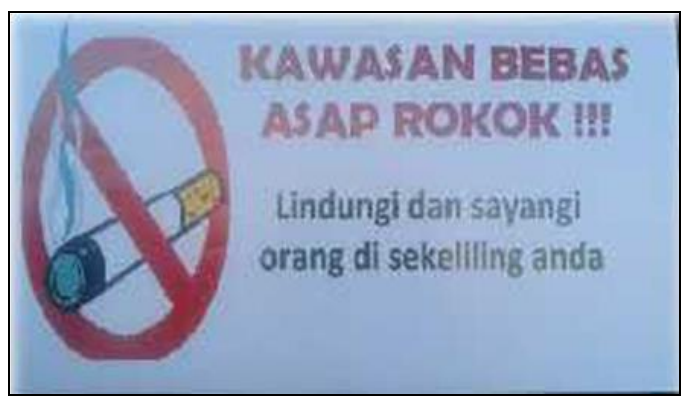

Gambar 5. Bebas area merokok

3. Kampung Asuh

Kampung Asuh merupakan perwujudan kepedulian warga pada setiap anak-anak yang mampu memberikan kebebasan untuk berekspresi. Kampung asuh ( TPA) yaitu warga Kampung RW 01 mempunyai kesadaran terhadap pengasuhan anak-anak sesuai dengan kebutuhan tumbuh kembang anak-anak. Pengasuhan terhadap anak-anak ditempatkan di balai RW. Untuk terbentuknya kampung asuh di wilayah RW 01 yaitu dengan memberikan Pendidikan Keluarga (BKB, BKR). Di kampung tersebut disediakan fasilitas yang menunjang bagi anak-anak seperti arena bermain serta permainan tradisional lainnya. Hal ini didukung oleh pendapat Santrock (2007) mengungkapkan bahwa budaya merupakan suatu pola pengasuhan serta perilaku kepercayaan dari satu kelompok orang tertentu dari generasi ke generasi.

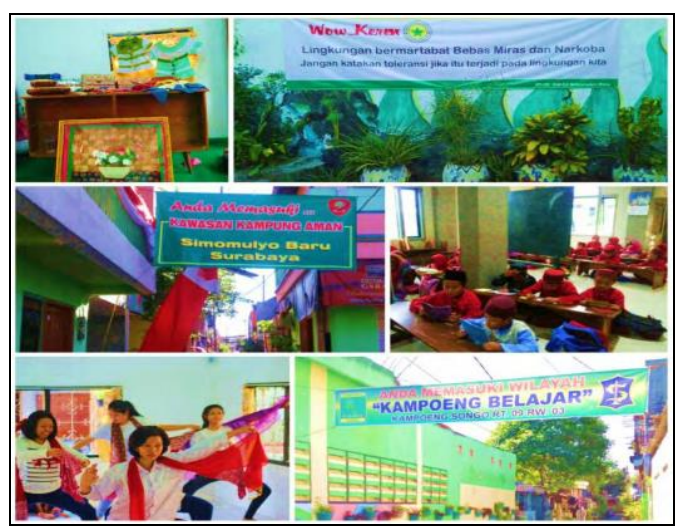

Gambar 6. Suasana Kampung Asuh

4. Kampung Aman

Kampung aman adalah program untuk meningkatkan keamanan dan mengoptimalkan partisipasi warga karena ini bagian dari kepentingan seluruh warga menur RT 01, 02, dan 03 dengan memasang banner di setiap sudut agar dapat dilihat oleh semua orang. Hal ini didukung oleh pendapat Roman (dalam Coetzee, 2005) merupakan penjabaran dari self esteem dimana tingkat kepercayaan dari seseorang, dan apa yang terbaik bagi diri dan bagaimana melakukannya. Selanjutnya menurut Maslow (dalam Awisol, 2009), kebutuhan manusia atas rasa aman menurut Maslow terbadi menjadi dua jenis antara lain penghargaan diri dan penghargaan dari orang lain. 


\section{Kampung Kreatif}

Kampung kreatif adalah merencanakan akan membentuk kegiatan agar anak-anak di sekitarnya menjadi lebih produktif yaitu melalui kegiatan drum band yang di lakukan oleh anak-anak PAUD dan kegiatan seni yaitu seni tari, karate. Seperti yang telah dilakukan oleh warga RW 01 berkenaan dengan penyambutan HUT RI ke 78 mereka mengecat paving jalan dan dinding tembok pada rumah warga. Dengan kreativitas ini bisa di manfaatkan utk tempat spot foto. Hal tersebut didukung oleh pendapat dari Florida (2002) pada artikel The Washington Monthly menyebutkan bahwa salah satu pembentuk kota yang kreatif yaitu dengan cara adanya komunitas kreatif. Komunitas sangat diperlukan untuk membantu menguatkan serta membentuk ruang yang kreatif. Komunitas kreatif dapat dideskripsikan sebagai sekumpulan individu yang mengharapkan suatu tempat untuk dapat menerima keberagaman dan keterbukaan terhadap gagasan serta ide baru (Widiastuti, 2015). Berdasarkan hal tersebut, maka diperlukan peran aktif antara pelaku wisata kreatif.

\section{SIMPULAN}

Dengan adanya program pendampingan KP-KAS oleh pendamping dari STIESIA Surabaya ini mampu menambah pengetahuan dan semangat para warga untuk mempersiapkan kampung RW 01 Menur Surabaya untuk lebih memaksimalkan persiapan KP-KAS ini sehingga RW 01 Menur Surabaya menjadi Kampung Layak anak. Program ini sangat diharapkan untuk generasi ke depan yang handal, bertanggungjawab, dan berprestasi serta peduli bagi lingkungan sekitarnya dan diharapkan agar lingkungan menjadi lebih nyaman, serta dapat terhindar dari sikap buruk seperti minuman keras, narkoba, dan kekerasan terhadap anak.

Mewujudkan Kampung Layak Anak pada program pendampingan KP- KAS tersebut diberi dukungan oleh berbagai macam pihak dengan keterbatasan serta keterbukaan atas suatu permasalahan yang akan dihadapi. Upaya dalam melaksanakan kegiatan agar dapat sesuai dengan apa yang diharapkan maka perlunya dukungan dan tanggungjawab atas kegiatan dan pengawasan yang dapat mencapai suatu tujuan organisasi dengan adanya evaluasi kerja.

\section{DAFTAR PUSTAKA}

Alwisol. 2009. Psikologi Kepribadian. Malang:UMM Press

Hasan. (2018). Kampung Pendidikan Dalam Pemberdayaan Partisipasi Masyarakat Desa Yang Berkarakter dan Berdaya Saing. Jurnal Terapan Abdimas, 3(2), 135-146.

Mochklas, M. Z. Rusmawati. A. Santoso. R. Jannah. (2019). Pendampingan Kampung Pendidikan Kampung'e Arek Suroboyo (Kp Kas) Rw 03 Kelurahan Ketintang Surabaya. Jurnal Komunitas: Jurnal Pengabdian kepada Masyarakat. 2(2), 51-59.

John, W. Santrock (2007). Perkembangan Anak. Jilid 1 Edisi kesebelas. Jakarta : PT. Erlangga

Rismaharini, T. (2019). Walikota Surabaya, buka Lomba Kampung Pendidikan Kampung'e Arek Suroboyo. Dinas Komunikasi dan Informatika Jawa Timur (Kominfo Jatim) (28 Agustus2019) kominfo.jatimprov.go.id

Kemenkes, RI (2011). Peraturan Mentri Kesehatan Republik Indonesia nomor 2269/MENKES/PER/XI/2011

Pedoman Pembinaan Perilaku Hidup Bersih dan Sehat (PHBS). Jakarta: Kementrian Kesehatan RI. http://www.promosikesehatan.com ( Diakses pada tanggal 7 Desember 2013 pukul 10 WIB ).

Radar, Surabaya (2019, 30 September). Kompak Jadikan Kampung Bersih dan Sehat.

Coetzee, M. 2005. Employee Commitment. University of Pretoria etd. http://upetd.up.ac.za/thesis/Avaiable/etd -0413200513064 . 